\title{
Analysis of Avicennia Sp. Plants Herbivory and Associated Insects in Mangrove Ecosystem Restoration
}

\author{
ANANG KADARSAH ${ }^{1}$, MUTIAH $^{1}$ AND SA $^{\prime}$ ADAH $^{1}$ \\ ${ }^{1}$ Biology Department, Faculty of Mathematics and Natural Sciences, Lambung Mangkurat University, \\ Ahmad Yani Street, Km 35.8, Banjarbaru, Indonesia
}

\begin{abstract}
Herbivory is a natural mechanisms for adjustment of tree growth, form, survivorship, and reproductive output of forest ecology including in mangrove ecosystem. The purpose of this study was to compare herbivory and insect diversity in various growth stages of Avicennia Sp. related with restoration of mangrove ecosystem. The research was carried out four months (July-October 2020) in Pagatan Besar mangrove ecosystem in Tanah Laut District, South Kalimantan Province. The results showed that marginal pattern is the most leaf attack case, both in every plant growth stages (39-68\%) and canopy (53-58\%) of Avicennia Sp. The highest average of leaf damage was found in lower canopy (3.06\%), and the growth stage of seedling (3.62\%). Herbivory most often found at lower canopy $(3.17 \%)$ and seedling life stages $(3.76 \%)$ of Avicennia Sp. It was found about 13 species of insects in all growth stages of Avicennia Sp. with the highest Biodiversity Index found in seedling (0.753). Insects function on all life stages of Avicennia Sp. was dominated by predator.
\end{abstract}

Keywords: Avicennia, herbivory, insect, mangroves

\section{INTRODUCTION}

Most mangrove forests in the tropical areas consist of monocultural stands or mixtures of a few tree species (Burrows, 2003). Avicennia sp. is one kind of true mangrove (Alongi, 2008), with the structural and floristic diversity arranges by the leaf (Burrows, 2003). The performance of Avicennia Sp. depends on Avicennia's growth stages, the interactions

Correspondence: Anang Kadarsah - Biology

Department, Faculty of Mathematics and Natural Sciences, Lambung Mangkurat University, Ahmad Yani Street, Km 35.8, Banjarbaru, South Kalimantan (70714); Email : anangkadarsah@ulm.ac.id between the tree and animals, and with the insects (Rinker \& Lowman, 2004).

Herbivoral insects play an important regulatory function in the ecology of forest ecosystems., The presence of the herbivoral insect affect the shape of Avicennia due to the insects predation on Avicennia leaf (Amalia et al., 2019). The presence of insects also affects significantly the longevity of leaves, time of leaf fall, and the quality of leaf litter, especially in young plant seeds (Burrows, 2003). Moreover, predation of insect on Avicennia lead to increase of nutrient cycle in forest ecosystem. In the other hand, the presence of insects and other herbivores in roots, stems and leaves of

Journal of Wetlands Environmental Management

Vol 9, No 1 (2021) 59 - 69

http://dx.doi.org/10.20527/jwem.v8i2.261 
Avicinnia cause of nutrient loss from plants (Cannicci et al., 2008). Herbivorous insect is affected by the tidal inundation modes in mangroves. The tidal movement affects insects living in the lower canopy, movement of nonflying insects (mostly larvae) from tree to tree, and emergency og pupate living in the soil (Burrows, 2003).

Herbivory is a natural mechanisms where the animals feed plant. The animals that eat plants is called herbivore. Herbivory affects plant growth, canopy form, seed survivorship, and reproductive growth stages of plant (Kairo et al., 2001: Burrows, 2003). Herbivory may damage apical leaf and shoot. However, herbivores also involve several useful mechanisms in the appearance of vegetation. The changes of stand performance is very useful indicators for natural ecosystem (Ansari et al., 2014) and the success of mangrove restoration effort (Devi \& Pathak, 2016).

For the recent research herbivory has shown a significant role of insects in mangrove ecosystems more important than previously (Rinker \& Lowman, 2004). .

Pagatan Besar mangrove ecosystem is one location of mangrove restoration in South Kalimantan Province where Avicennia Sp. is the dominant indigenous plant. However, there is still no comprehensive data about herbivory and number or type of in Pagatan Besar as affected by restoration project. Information on herbivory and insect are needed for understanding of plant-host interaction and for managing the resistance and sustainability of restoration efforts. The purpose of this study was to compare herbivory and insect diversity in various life stage of Avicennia Sp. related with restoration of mangrove ecosystem.

Journal of Wetlands Environmental Management

Vol 9, No 1 (2021) 59 - 69

http://dx.doi.org/10.20527/jwem.v8i2.261

\section{MATERIALS AND METHODS}

\section{Study sites}

The study was conducted in Pagatan Besar, Tanah Laut Regency, South Kalimantan, Indonesia (Figure 1). The area has been under restoration project by Provincial Government of South Kalimantan since 2003 (Soendjoto, 2003). The study was carried out from July until October 2020.

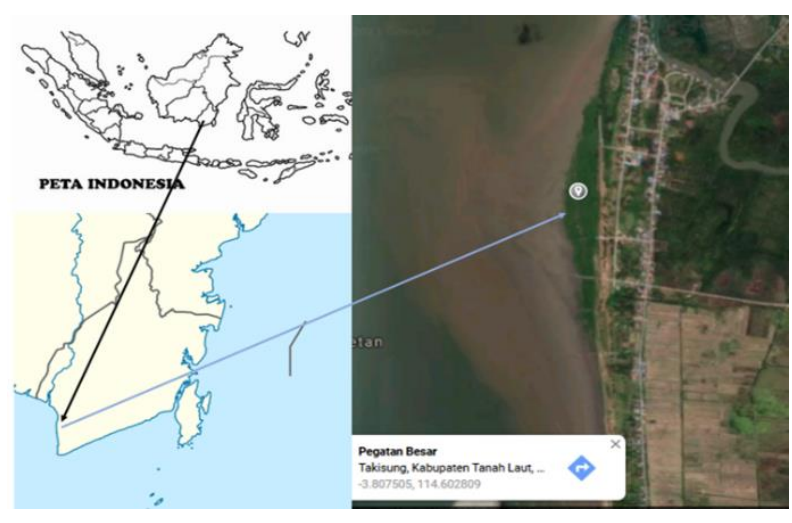

Figure 1. Sampling sites in Pagatan Besar mangrove ecosystems, Tanah Laut, South Kalimantan, Indonesia (latitude: -3.8085378502031086, longitude: $114.60293845489215)$

\section{Sampling and assay}

This research used discrete methode. Herbivory was carried out by collecting leaves in the field and analysing them in the laboratory., Capture technique was used to observe herbivores habits through visual observation (Burrows, 2003). A direct one-time method was employed to compare areas of leaf damage between samples (Burrows, 2003). Leaf samples were taken from three different Avicennia $\mathrm{Sp}$ growth stages (seedling, sapling, and tree) and canopy parts 
(lower canopy and upper canopy). Herbivory measurements was carried out using the method as described by Rinker \& Lowman (2004). In this method, three research stations were established based on the Avicienna growth stages. Three plots $(10 \mathrm{~m}$ x $10 \mathrm{~m})$ were established in each station. From each plot three plants were chosen as sample and the total of six hundred leaves were taken from all stations (Figure 2).

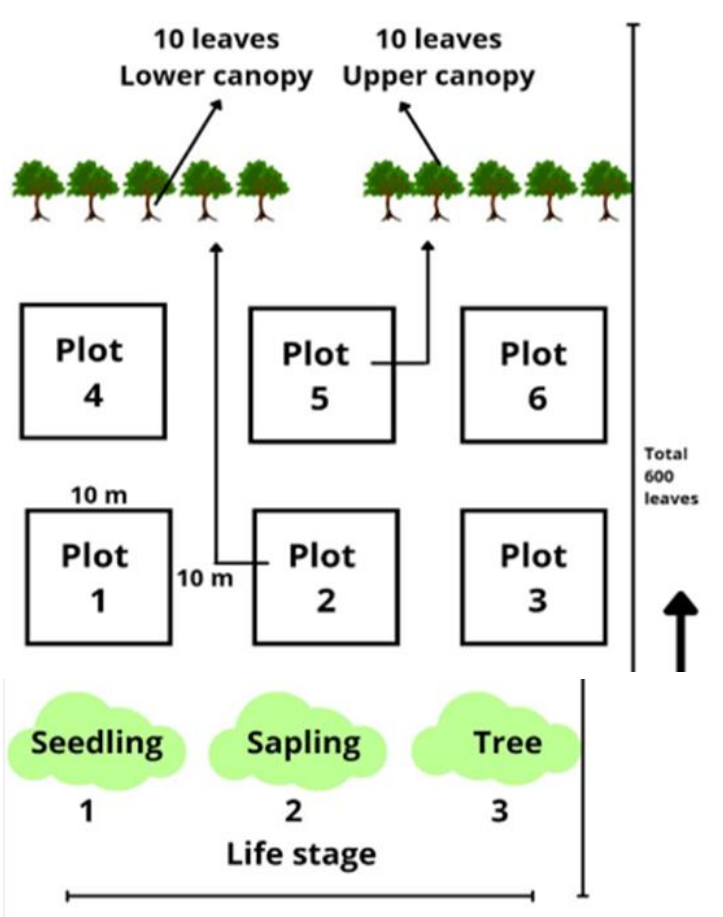

Research Station

Figure 2. Sampling methods of herbivory.

The area of leaf damaged was then quantified using a millimeter block paper. The leaves are then sorted based on the attack pattern category (i.e., marginal, internal, and combination) and the condition of the leaves (i.e., intact or damaged). There are three parameters used to calculate herbivory i.e., 1) attack patterns, 2) leaf damage, and 3) comparison of herbivory. Attack patterns were classified based on visual observation into (1) marginal, (2) internal, and 3) combined between marginal and internal. This observed data then divided by the total attack pattern and multiplied by 100 in the form of a percent (\%) (Kathiresan, 2003). Damaged leaf area was divided by intack leaf and multiply by 100 to quantify the \% leaf damaged. Generally, there are four types of leaf damage, i.e., type I (1 - 20\%), type II (21 - 40\%), type III (41 - 60\%) and type IV (61 - 80\%) (Burrows, 2003). Similarly, the comparison of herbivory was calculated with formula : $\%$ Herbivori in a given leaf $=\frac{\Sigma \mathrm{fx}}{\Sigma \mathrm{f}}$, that $\mathrm{f}$ is frequency of leaf area no exposed to herbivores, and $\mathrm{x}$ is percentage of leaf area consumed by herbivores (Saifullah \& Ali, 2004).

\section{Diversity of insects}

Insect samples were taken using the Yellow Pan Trap method and direct collection 3 times along with leaf sampling for herbivory observation. Insect identification uses reference sources such as (Borror et al., 2005) and insect data search tools on https://www.insectidentification.org/ page. The Shannon-Wiener Diversity Index $(\mathrm{H})$ is calculated using the following equation : $\mathrm{H}=-\sum$ $\mathrm{P}_{\mathrm{i}}\left(\ln \mathrm{P}_{\mathrm{i}}\right) \quad$ where $\mathrm{P}_{\mathrm{i}}$ is the proportion of each species in the sample (Mendes et al., 2008). Three parameters used were the type, diversity and density of insects at each level of plant life Avicennia $\mathrm{Sp}$. The relationship between hebivory events and the presence of insects is in accordance with the succession of the mangrove ecosystem. Survival rate of Avicennia Sp. with the type and density of insects were analyzed 
using Chi-Square at a confidence level of $95 \%$.

\section{RESULTS}

\section{Attack patterns}

In general, there are three known patterns of herbivory attack, the first is attack direction start from the edge of leaf (marginal), second is starting from the middle (internal) and third the attacks starting with the edge and also int the middle (combination). From the Figure 3 below, we found an example attack pattern on the leaves of Avicennia Sp. plant, i.e., marginal patterns (A), internal patterns (B), and combination patterns (C) from Avicennia Sp. in Pagatan Besar mangrove ecosystem, of South Kalimantan.

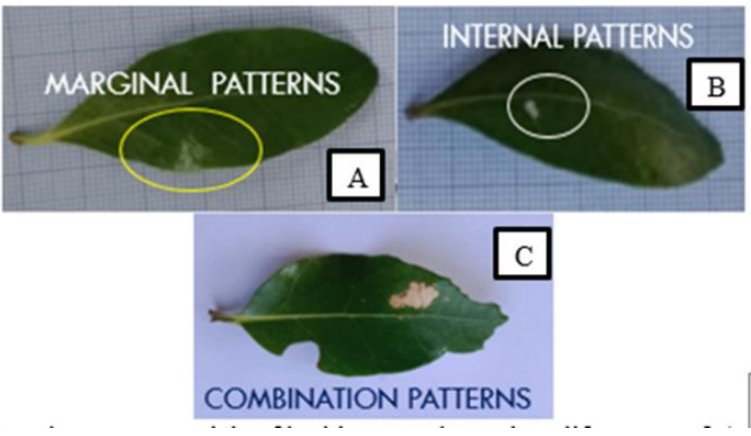

Figure 3. Attack patterns models of herbivory at the various life stages of Avicennia Sp. (A. Marginal patterns, B. Internal patterns, C. Combination patterns).

Based on the development on all life stages (seedling, sapling and tree) of Avicennia Sp., found the most accident is marginal attack patterns $(39-68 \%)$, and then the internal attack pattern $(23-45 \%)$, and the lowest is combination patterns $(9-16 \%)$. See Figure 4 below.

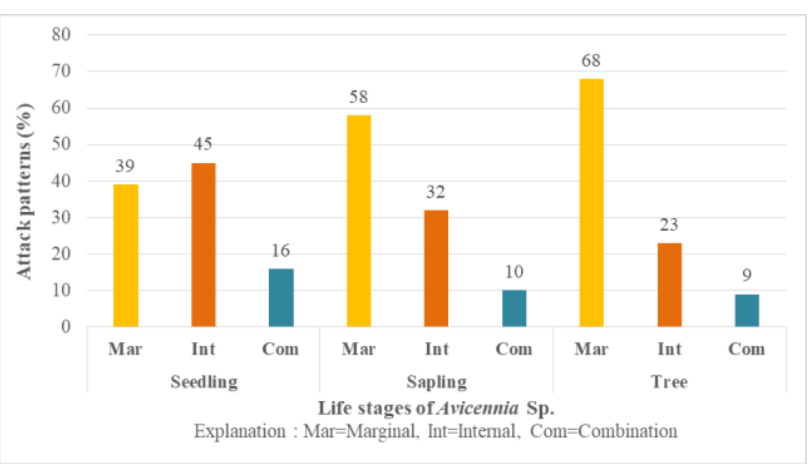

Figure 4. Comparison attack patterns of herbivory $(\%)$ at the various life stages of Avicennia Sp.

Compared with canopy position, its also dominated by marginal attack patterns both in lower and top of the Avicennia Sp.canopy (53$58 \%$ ). And the lowest is combination attack patterns with value from $10.33-13 \%$. All of this can be seen in Figure 5 below.

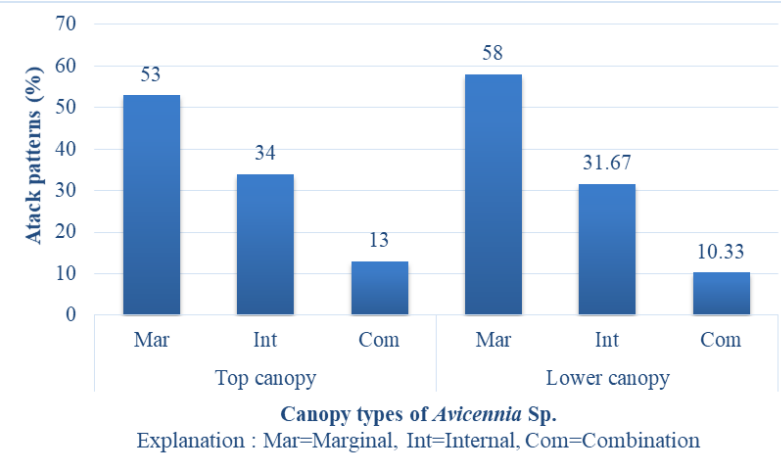

Figure 5. Comparison of herbivory attack patterns (\%) in the canopy of Avicennia Sp.

\section{Attack patterns}

Results average analysis of leaf damage in Avicennia $\mathrm{Sp}$. on the upper canopy recorded at $2.54 \%$, which is lower than the lower canopy $(3.06 \%)$ (Figure 6.left). Meanwhile, based on the life stages of Avicennia Sp., it is known that the highest mean values were carried out from seedling (3.62\%) and the lowest from sapling

Journal of Wetlands Environmental Management 
(2.45\%) (Figure 6, right). All of this explanation can be seen in the Figure 6 below.

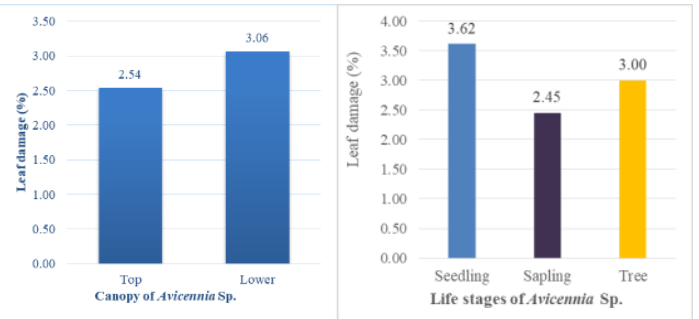

Figure 6. Leaf damage (\%) at the canopy (left), and at the life stages of Avicennia Sp. (right).

\section{Herbivory}

The results showed (Figure 7, left) that the highest herbivory value was obtained from the lower canopy (3.17\%). Meanwhile, based on the life stages of Avicennia Sp. (Figure 7, right side) obtained the highest herbivory value from the seedling period $(3.76 \%)$.
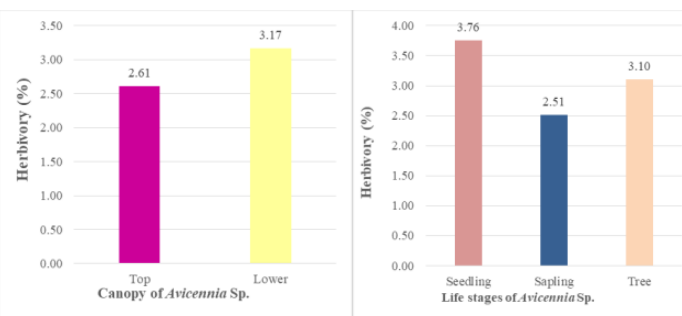

Figure 7. Comparison of herbivory at the canopy (left) and at the life stages of Avicennia Sp. (right).

\section{Insects Diversity}

There are approximately 13 types of insects found in Avicennia Sp. They are Archichauliodes diversus, Blattella germanica,
Camponotus maculatus, Chrysomya megacephala, Dolomedes triton, Drosophila melanogaster, Echthromorpha intricatori, Limonethe maurator, Microchrysa polita, Philanthus gibbosus, Pseudomyrmex gracilis, Tanystoma maculicolle, and Xanthocryptus novozealandicus. The percentage value of the presence of Chrysomya megacephala (Decomposer : Family Calliphoridae) was the highest (20.2\%) in all the life levels of Avicennia Sp.. Then followed by Tanystoma maculicolle (Predator: Family Carabidae) by $17.2 \%$ and Pseudomyrmex gracilis (Predator: Family Formicidae) by $16.6 \%$. The complete results are seen in Table 1 below.

Attendance of insect based on its function on all life stages of Avicennia Sp. show the highest value get from the insect predator type (Carabidae, Corydalidae, Crabronidae,

Ichneumonidae, Pisauridae, Stratiomyidae and Formicidae) about 60\%, then decomposer (Calliphoridae) about 20\%, herbivore (Drosophilidae) $11 \%$ and the lowest is detritivore (Ectobiidae and Stratiomyidae) 9\%). All of this information can be seen in Figure 8 below.

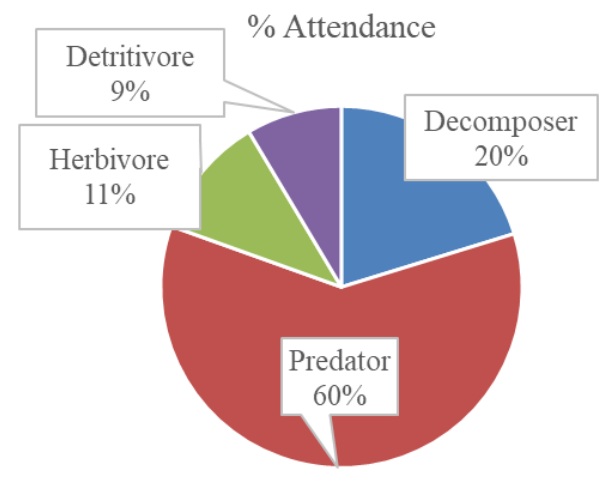

Figure 8. Attendance of insects family (A) and its function (B) on all the life stages of Avicennia Sp. 
Table 1. Insects attendance on various life stages of Avicennia Sp. from Pagatan Besar mangrove ecosystem

\begin{tabular}{clllc}
\hline No. & \multicolumn{1}{c}{ Name of Insect } & \multicolumn{1}{c}{ Family } & \multicolumn{1}{c}{$\begin{array}{c}\text { Food web } \\
\text { Function }\end{array}$} & $\begin{array}{c}\text { \% } \\
\text { Attendance }\end{array}$ \\
\hline 1 & Chrysomya megacephala & Calliphoridae & Decomposer & 20.2 \\
2 & Tanystoma maculicolle & Carabidae & Predator & 17.2 \\
3 & Pseudomyrmex gracilis & Formicidae & Predator & 16.6 \\
4 & Drosophila melanogaster & Drosophilidae & Detritivor & 11.0 \\
5 & Echthromorpha intricatoria & Ichneumonidae & Predator & 10.0 \\
6 & Microchrysa polita & Stratiomyidae & Detritivor & 7.4 \\
7 & Limonethe maurator & Ichneumonidae & Predator & 4.3 \\
8 & Camponotus maculatus & Formicidae & Predator & 3.3 \\
9 & Dolomedes triton & Pisauridae & Predator & 3.3 \\
10 & Philanthus gibbosus & Crabronidae & Predator & 2.2 \\
11 & Xanthocryptus & Ichneumonidae & Predator & 2.2 \\
12 & Archichauliodes diversus & Corydalidae & Predator & 1.1 \\
13 & Blattella germanica & Ectobiidae & Detritivor & 1.1 \\
\hline
\end{tabular}

Note: ${ }^{1)}$ averaged values from 3 replicate. 
The counting of insect biodiversity using Shannon-Wiener Index (Mason, 2002) from the various life stages of Avicennia Sp. in Pagatan Besar mangrove ecosystem show the highest value for seedling at 0.753, and the lowest for sapling (0.044). All values derived from these calculations are indicates a low species diversity. The result can be seen in the Figure 9 below.

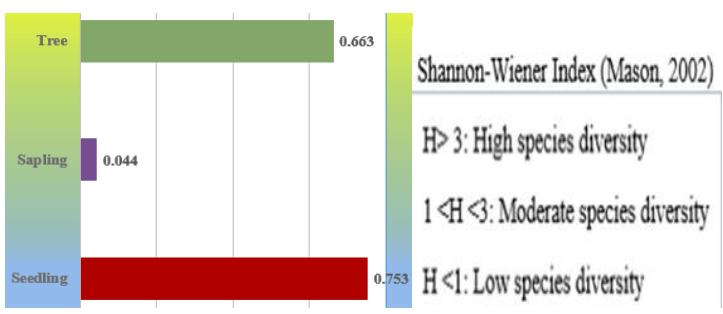

Figure 9. Shannon-Wiener Biodiversity Index of Insect from the various life stages of Avicennia Sp in Pagatan Besar mangrove ecosystem of South Kalimantan, Indonesia.

\section{Correlation between type and number of insects with herbivory}

Analysis of the correlation between types and numbers of insects with attack patterns and herbivores at various life stages of Avicennia Sp. show a higher value than the standard $(\alpha=0.05)$ as shown in the Table 1 below. Generally of conclusions, there was no influence between the type and number of insects on attack patterns (both in internal, marginal and combined) and also for herbivory in Avicennia Sp. leaves.
Table 2. Correlation coeficients of types and number of insects with attack pattern and herbivory $(\alpha=0.05)$.

\begin{tabular}{lcc}
\hline \multicolumn{1}{c}{ Parameters } & $\begin{array}{c}\text { Attack } \\
\text { Pattern }\end{array}$ & Herbivory \\
\hline $\begin{array}{l}\text { Types of } \\
\text { Insects }\end{array}$ & 0.315 & 0.211 \\
$\begin{array}{l}\text { Number of } \\
\text { Insects }\end{array}$ & 0.865 & 0.880 \\
\hline
\end{tabular}

\section{DISCUSSION}

\section{Attack Patterns}

Our results showed that herbivory can be found on all parts of canopy (lower and top) with variable patterns and plant growth stages (Figures 2-4). It indicates that herbivory attack has spread to all parts of Avicennia Sp. These can have different effects and consequences for plants both ecological and evolutionary (Mello, 2007). Variable effects of herbivory at different growth stages can be caused by plants in developing different resistance against attacks by herbivores, as also reported by Da Silva et al. (2015). It seems that these qualities possessed by plants serve as a better defense because they have a direct effect on the fertility and survival of the herbivores rather than the effects of predation (Lill \& Marquis, 2001).

\section{Leaf damage}

Zvereva \& Kozlov (2014) divided the levels of damage (proportion of damaged leaf area) into three groups: low $(<10 \%)$, moderate $(11-49 \%)$ and high $(>50 \%)$. Meanwhile there were nine damage types from their research:

Journal of Wetlands Environmental Management 
holes, fungal spots, galls, undefined damage, margin damage, mining, necrosis, eggs, and rasping. The leaf herbivory percentages we found were lower as compared to other mangrove forests de Menezes \& Peixoto (2009), most likely due to the high values of interstitial salinity (Da Silva et al., 2015).

\section{Herbivory}

The herbivory value obtained from this study is smaller than the herbivory value obtained from the research results of Amalia et al (2019), namely A. marina (4.66 $11.59 \%)$ and R. mucronata (5.23 - $12.44 \%$ ). The herbivory attacks intensity sometimes increases and capable to destroy the target of plant, but sometimes it failurer to attack the target. This is because the plants have a physical, mechanical and chemical defense mechanisms such as secondary metabolites(Rinker \& Lowman, 2004). Variability in plant responses to herbivory may be linked with the leaf economic spectrum. Premature abscission of damaged leaves can be seen as a tolerance strategy that reduces the negative consequences of local damage on the whole plant (Zvereva \& Kozlov, 2014; Burrows, 2003).

\section{Insect diversity}

The insect families found in this study differed with those found by Dwihandayani's (2017) who found the most frequent insect families were Acrididae, Formicidae, Chrysomelidae, Tettiginidae, and Gryllidae in the Batutegi Tanggamus Protected Forest Area in Lampung. There are many factors which

Journal of Wetlands Environmental Management Vol 9, No 1 (2021) 59 - 69 http://dx.doi.org/10.20527/jwem.v8i2.261 influence insect herbivore diversity and it can be viewed at several scales. At the whole ecosystem level, insect herbivore diversity is affected by the variety of the vegetation types present whilst the diversity of insects attacking individual tree species depends on factors such as the trees' geographic range, their architecture, their chemical and physical defense mechanisms and the number of their nearby conspecifics (Burrows, 2003).

\section{CONCLUSIONS}

Attack patterns on all life stages of Avicennia Sp. showed that marginal pattern is the most frequent, both in every plant growth stages (39$68 \%$ ) and canopy (53-58\%). Herbivory on all plant growth stages of $(2,51-3,71 \%)$ indicated that Avicennia Sp. was in a normal or healthy conditions. We found that the insects function on all growth stages of Avicennia Sp. was dominated by predator.

\section{ACKNOWLEDGMENT}

This research was funded by Research and Public Servise Agency of Lambung Mangkurat University (Contract No: .../2020). Gratutide goes to Mutiah and Saadah, students of Biology Studi Program who have helped carry out research and data collection in the field.

\section{REFERENCES}

Alongi, D. M. (2008). Mangrove forests : Resilience, protection from tsunamis, and responses to global climate change. Estuarine, Coastal and Shelf Science, 76, 1- 


\section{3.}

https://doi.org/10.1016/j.ecss.2007.08.024

Amalia, E., Pramesti, R., Pribadi, R., \&

Setyati, W. A. (2019). Tingkat Herbivori

Daun Avicennia marina (forssk.) Vierh dan Rhizophora mucronata di Vegetasi Mangrove-Timbulsloko, Demak. Jurnal Enggano, 4(2), 128-135.

Ansari, A. A., Trivedi, S., Saggu, S., \& Rehman, H. (2014). Mudskipper: A biological indicator for environmental monitoring and assessment of coastal waters. Journal of Entomology and Zoological Studies, 2(6), 22-33.

Borror, D. J., Delong., D. M., Triplehorn, C. A., \& Johnson, N. F. (2005). Introduction to the Study of Insects (7th Editio). Thomson Brook, USA.

Burrows, D. W. (2003). The role of insect leaf herbivory on the mangroves Avicennia marina and Rhizophora stylosa [James Cook University]. https://researchonline.jcu.edu.au/1174/2/0 2whole.pdf

Cannicci, S., Burrows, D., Fratini, S., Smith, T. J., Offenberg, J., \& Dahdouh-Guebas, F. (2008). Faunal Impact on Vegetation Structure and Ecosystem Function in Mangrove Forests: A Review. Aquatic Botany, 89, 186-200.

Da Silva, W. A., Lage-Pinto, F., \& Bernini, E. (2015). Leaf damage in three mangrove forests in Northeast Brazil. Pan-American Journal of Aquatic Sciences, 10(3), 239248.

https://panamjas.org/pdf_artigos/PANAMJ AS_10(3)_239-248.pdf

Devi, V., \& Pathak, B. (2016). Ecological studies of mangroves species in Gulf of Journal of Wetlands Environmental Management Vol 9, No 1 (2021) 59 - 69 http://dx.doi.org/10.20527/jwem.v8i2.261
Khambhat, Gujarat. Tropical Plant Research, 3(3), 536-542. https://doi.org/10.22271/tpr.2016.v3.i3.070

Kairo, J. G., Dahdouh-Guebas, F., Bosire, J., \& Koedam, N. (2001). Restoration and management of mangrove systems - A lesson for and from the East African region. South African Journal of Botany, 67(3), 383-389. https://doi.org/10.1016/S02546299(15)31153-4

Kathiresan, K. (2003). Insect Foliovory in Mangroves. Indian Journal of Marine Sciences, 32(September), 237-239.

Lill, J. T., \& Marquis, R. J. (2001). The effects of leaf quality on herbivore performance and attack from natural enemies. Oecologia, 126 , 418-428. https://doi.org/10.1007/s004420000557

Mason, C. F. (2002). Biology of Freshwater Pollution. Prentice Hall. https://books.google.co.id/books?id=MNXC $\mathrm{r} 4 \mathrm{VtaK} 4 \mathrm{C}$

Mello, M. A. R. (2007). Influence of herbivore attack patterns on reproductive success of the shrub Piper hispidum (Piperaceae). Ecotropica, 13(1), 1-6. https://www.soctropecol.eu/PDF/Ecotropica _2007_01/Mello 2007, Ecotropica 13-1.pdf

Mendes, R. S., Evangelista, L. R., Thomaz, S. M., Agostinho, A. A., \& Gomes, L. C. (2008). A Unified Index to Measure Ecological Diversity and Species Rarity. Ecography, 31(4), 450-456. http://www.jstor.org/stable/30244598

Rinker, H., \& Lowman, M. (2004). Chapter 18. Insect Herbivory in Tropical Forests. In M. D. Lowman \& H. B. Rinker (Eds.), Forest Canopies (Second Edi, pp. 3-18). Elsevier Academic Press. 
Saifullah, S. M., \& Ali, M. S. (2004). Insect herbivory in polluted mangroves of the Indus Delta. Pakistan Journal of Botany, 36(1), 127-131. https://www.researchgate.net/profile/Syed _Saifullah/publication/258885622_Insect_ herbivory_in_polluted_mangroves_of_the _Indus_Delta/links/00b7d5295a66f05c4b0 00000/Insect-herbivory-in-pollutedmangroves-of-the-IndusDelta.pdf?_sg\%5B0\%5D=v24Vm8Y7XLf $7 \mathrm{sFf} 4 \mathrm{Fho}$

Soendjoto, M. A. (2003, April). Hutan mangrove Pegatan Besar: Hikmah dari sebuah musibah. Warta Koservasi Lahan Basah Vol 11 No 2, April 2003, 26-27.

Zvereva, E. L., \& Kozlov, M. V. (2014). Effects of herbivory on leaf life span in woody plants: A meta-analysis. Journal of Ecology, 102(4), 873-881. https://doi.org/10.1111/1365-2745.1225 